\title{
Responses of seagrass to nutrients in the Great Barrier Reef, Australia
}

\author{
James W. Udy ${ }^{1,2, *}$, William C. Dennison ${ }^{1}$, Warren J. Lee Long ${ }^{3}$, Len J. McKenzie ${ }^{3}$ \\ ${ }^{1}$ Department of Botany, University of Queensland, Brisbane, 4072 Queensland, Australia \\ ${ }^{2}$ Centre for Catchment and In Stream Research, Griffith University, Nathan, 4111 Queensland, Australia \\ ${ }^{3}$ Queensland Department of Primary Industries, Northern Fisheries Centre, Cairns, 4870, Queensland, Australia
}

\begin{abstract}
Declines in seagrass biomass and growth have been widely reported in response to anthropogenic impacts. In contrast, the distribution and biomass of seagrass in the carbonate sediment around Green Island reef, part of Australia's Great Barrier Reef (GBR), has measurably increased during the past $50 \mathrm{yr}$, possibly due to increases in the availability of nutrients from local and regional anthropogenic sources. Using historical aerial photography, increases in seagrass distribution at Green Island have been mapped. The growth, morphological and physiological responses of 2 seagrass species (Halodule uninervis and Syringodium isoetifolium) to elevated sediment nitrogen ( $\mathrm{N} ; 100 \times$ control) and/or phosphorus $(\mathrm{P} ; 10 \times$ control) were measured to investigate whether increased nutrients could account for the observed increase in distribution. Increases in the growth rate, amino acid composition and tissue nutrient content of both species occurred in response to elevated sediment $N$, but not $P$. Concentrations of the $\mathrm{N}$-rich amino acids asparagine and glutamine increased 3 - to 100 -fold in seagrass leaves from $\mathrm{N}$ treatments. The $\delta^{15} \mathrm{~N}$ values of leaves decreased in response to additions of nitrogen, probably due to increased discrimination against the ${ }^{15} \mathrm{~N}$ isotope, because $\mathrm{N}$ availability was surplus to demand. The low $\delta^{15} \mathrm{~N}$ value of seagrasses in the Green Island back reef suggests that their primary source of $\mathrm{N}$ is either from $\mathrm{N}_{2}$ fixation or fertilisers and that the $\mathrm{N}$ from sewage is not a large component of their $\mathrm{N}$ budget. This study is the first to demonstrate $\mathrm{N}$, rather than $\mathrm{P}$, as the primary limiting nutrient for growth of seagrass in carbonate sediments and supports the hypothesis that the increase in the seagrass distribution and biomass at Green Island was caused by an increase in nutrient availability. We also hypothesise that seagrass distribution and biomass in many regions of the GBR may be limited by nutrients and that the lack of substantial seagrass meadows in the southern GBR could be due to these reefs receiving less nutrients from the mainland.
\end{abstract}

KEY WORDS: Seagrass · Great Barrier Reef · Nutrients

\section{INTRODUCTION}

Phosphorus is the most likely nutrient to limit the growth of seagrass in carbonate substrata due to strong binding of $\mathrm{PO}_{4}{ }^{3-}$ by carbonate ions (Lide 1994) and fast rates of $\mathrm{N}_{2}$ fixation by microorganisms in tropical sediments (Smith \& Hayasaka 1982, Capone et al. 1992, Welsh et al. 1996). Experimental fertilisation of seagrasses growing in carbonate sediment in the Bahamas and Florida Bay, USA, have reported limitation of seagrass growth by $\mathrm{P}$ availability (Short et al. 1985, 1990, Fourqurean et al. 1992a, b). Carbonate sediment usually dominates in regions that receive little or no riverine inputs of sediment or nutrients. Thus, the growth of

•E-mail: j.udy@mailbox.gu.edu.au seagrass in carbonate sediments could also be limited by the availability of micronutrients such as iron, which are derived from terrigenous soil (Duarte et al. 1995).

Anthropogenic nutrient inputs to reef ecosystems have caused a detrimental effect on, or loss of, the existing coral communities in many parts of the world. The discharge of sewage into Kaneohe Bay, Hawaii, resulted in the ecosystem becoming dominated by plankton, benthic filter feeders and algae with sections of the bay losing $99.9 \%$ of their corals (Maragos et al. 1985). Loss of corals and the proliferation of macroalgae have also been associated with the discharge of sewage and anthropogenic nutrient sources in the Red Sea (Walker \& Ormond 1982), Japan (Kuhlman 1988), Bermuda (Bach \& Josselyn 1978) and Florida, USA (Lapointe 1989). 
At Green Island, a tropical coral cay on the Great Barrier Reef (GBR), $27 \mathrm{~km}$ northeast of the Australian mainland, seagrasses grow in predominantly carbonate sands (>90\% $\mathrm{CaCO}_{3}$ i Allan \& Johns 1989). The distribution of seagrass has increased substantially over the last $50 \mathrm{yr}$ (Kuchler 1978, Baxter 1990) and now extends from the intertidal reef flat to a depth of at least $15 \mathrm{~m}$ on the back-reef slope. This increase in the distribution and biomass of seagrass has been circumstantially linked to an increase in the availability of nutrients near Green Island, associated with greater amounts of tourism and the installation of a sewage outfall pipe in 1972 (van Woesik 1990). It is also possible that regional increases in nutrient supply to the coastal zone have contributed to the observed increases in the distribution of seagrass at Green Island. At Low Isles, an inner-reef coral cay $60 \mathrm{~km}$ north of Green Island with limited local inputs of nutrients, the distribution of mangrove communities increased $67 \%$ between 1929 and 1973 (Stoddart et al. 1978) and seagrass distribution has also been observed to increase (I. Abbott pers. comm.). This indicates that regional sources of nutrients may be affecting the distribution of mangroves and seagrasses in the Cairns region of the GBR.

Using aerial photography and ground surveys we have established the current seagrass distribution on Green Island and investigated, using a fertilisation experiment, if seagrass growth at Green Island is limited by the availability of nitrogen and/or phosphorus. $\delta^{15} \mathrm{~N}$ values of seagrasses were also sampled to identify their primary source of $N$. If sewage is the primary $\mathrm{N}$ source the $\delta^{15} \mathrm{~N}$ is expected to be close to 10 , while $\delta^{15} \mathrm{~N}$ values close to 0 suggest that $\mathrm{N}_{2}$ fixation or fertilisers are the primary $\mathrm{N}$ source (Grice et al. 1996, Udy \& Dennison 1997a, b).

\section{MATERIALS AND METHODS}

Study site. Green Island (16 $\left.45^{\prime} \mathrm{S}, 1^{\circ} 45^{\circ} 59^{\prime} \mathrm{E}\right)$, located in the central portion of Australia's Great Barrier Reef (GBR), is a coral cay of 12 ha on a platform coral reef (170 ha), rising 35 to $40 \mathrm{~m}$ above the interreefal seafloor (Fig. 1). The GBR consists of numerous reefs, some with cays, and extends from the Gulf of Papua $\left(9^{\circ} \mathrm{S}\right)$ to the Capricorn Bunker Group $\left(24^{\circ} \mathrm{S}\right)$.
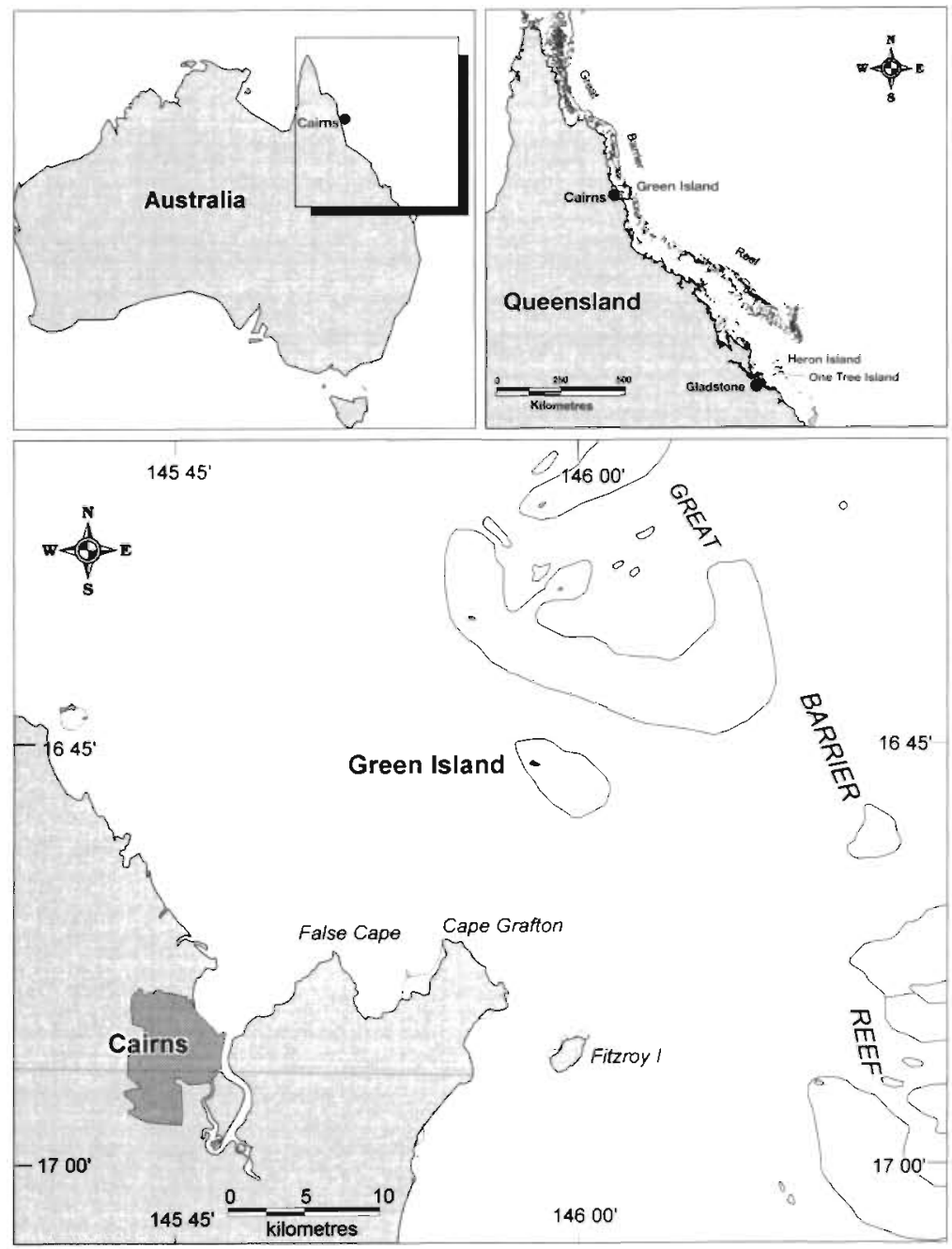

Fig. 1 The Great Barrier Reef is located off the northeastern coast of Australia and extends from the Gulf of Papua $\left(9^{\circ} \mathrm{S}\right)$ to the Capricorn Bunker Group $\left(24^{\circ} \mathrm{S}\right)$. Green Island is Iocated $27 \mathrm{~km}$ NE of the Australian mainland in the middle of the Great Barrier Reef 'Iagoon'

The GBR region includes a series of 'outer reefs' which are located near the edge of the continental shelf, numerous 'inner reefs', including Green Island, and the GBR 'lagoon' between the outer-reefs and the mainland.

Green Island is covered by a closed vine forest ( $84 \%$ ) and surrounded by unvegetated beach rock and sand (Stoddart et al. 1978). Unlike many other coral cays on the GBR, Green Island is not a significant nesting site for seabirds (Australian Littoral Society 1990) and hence receives minimal nutrients from avian sources. The reef platform on the southern and eastern sides of Green Island is covered mostly with low density seagrasses (Thalassia hemprichii and Halodule uninervis). The northwestern subtidal region supports relatively dense meadows of Halodule uninervis mixed with other seagrass species (Syringodium isoetifolium, 
Cymodocea rotundata, C. serrulata, Halophila ovalis). The fertilisation study was situated in the subtidal ( $\sim 2 \mathrm{~m}$ deep at mean low water) $400 \mathrm{~m}$ northwest of Green Island (Fig. 2).

A 7 ha National Park is located at the eastern end of Green Island with a tourist resort located on the western end. The first lease for resort development on Green Island was granted in 1938. Since then tourism has increased and Green Island is currently the most highly visited location on the GBR receiving 300000 tourists $\mathrm{yr}^{-1}$ (Great Adventures pers. comm.). Green Island changed from septic to sewage treatment in 1972 with effluent discharge occurring on the southwest reef edge until December 1992, when tertiary treatment was installed. Tertiary treated water is currently reused on the island or discharged into the main channel and the sludge is removed by barge for disposal on the mainland.

Mapping methods. Digitally scanned and rectified vertical aerial photography (1:12000 and 1:6000) was used to map the present (1994) and past (1936, 1959 and 1972) seagrass distribution to the northwest of Green Island cay. Seagrass meadows

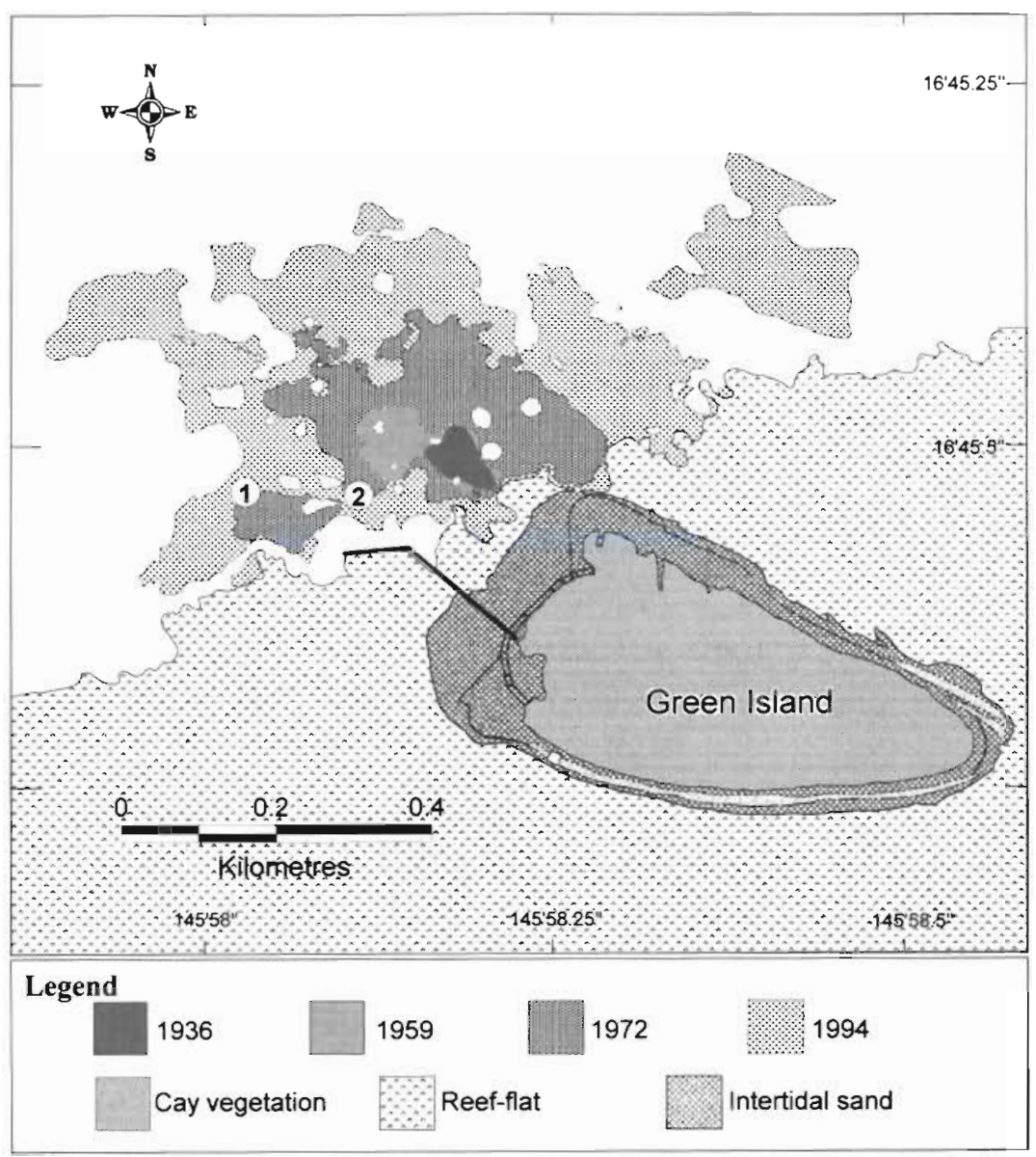

Fig. 2. Seagrass distribution and abundance at Green Island in 1994, 1972, 1959 and 1936. The fertilisation of the seagrass meadow dominated by Halodule uninervis (1) and the mixed meadow of $H$. uninervis and Syringodium isoetifolium (2) were located off the NW side of Green Island

in 1994 were ground-truthed be-

tween 17 August 1994 and 2 September 1994. Estimates of aboveground seagrass biomass ( 3 replicates of a $0.25 \mathrm{~m}^{2}$ quadrat) and the relative proportion of each seagrass species were recorded at 95 sites in the seagrass meadow. The sites were located, at least every $20 \mathrm{~m}$, along north-south transects, which were between 100 and $500 \mathrm{~m}$ apart.

Aboveground biomass was determined by a 'visual estimates of biomass' technique described by Mellors (1991). At each site, divers recorded an estimated rank of seagrass biomass. To estimate the relative aboveground biomass for each ranking, samples were collected and dried for each diver's rankings. Seagrass species were identified according to Kuo \& McComb (1989).

A theodolite was used to accurately determine geographic location of survey sites $( \pm 1.5 \mathrm{~m})$. All data was entered onto a geographic information system (GIS) using aerial photographic images (Queensland Beach Protection Authority, 28 June 1994, altitude $914 \mathrm{~m}$ ) rec- tified to Australian Map Grid (AMG) zone 55 co-ordinates, as the base map.

Boundaries of the seagrass meadow were determined based on the theodolite fix at each site and aerial photograph interpretation. Errors, which should be considered when interpreting GIS maps, include those associated with digitising and rectifying aerial photographs onto base maps and theodolite fixes for sites. The error in determining the seagrass distribution in this study was set at $\pm 5 \mathrm{~m}$ either side of the meadow edge. Other errors associated with mapping, such as GPS and the position of a diver under the vessel, were embedded within this range.

Past seagrass distribution was determined by scanning a vertical aerial photo from 1972 and visually interpreting and rectifying oblique aerial photos from 1936 and 1959 onto a GIS.

Fertilisation experiment. Fertilisation: Seagrasses were fertilised in situ at 2 sites: (1) an area dominated by Halodule uninervis with small amounts of Cymodo- 
cea rotundata, C. serrulata and Halophila ovalis; (2) a mixed bed of Syringodium isoetifolium and $H$. uninervis. Slow release fertiliser was applied in April and September 1994 (5 to 6 mo release Osmocote with phosphorus as $18 \% \mathrm{PO}_{4}{ }^{3-}$ and nitrogen as $11.5 \% \mathrm{NH}_{4}{ }^{+}$ and $11.5 \% \mathrm{NO}_{3}{ }^{-}$, Scotts Australia). Three replicates of 4 treatments were used at each site; Control (C: sediment disturbed but no fertiliser added), phosphorus $\left(+\mathrm{P}_{i} 23 \mathrm{~g} \mathrm{P} \mathrm{m}^{-2}\right)$, nitrogen $\left(+\mathrm{N}_{i} 88 \mathrm{~g} \mathrm{~N} \mathrm{~m}^{-2}\right)$ and nitrogen plus phosphorus $\left(\mathrm{N}+\mathrm{P} ; 23 \mathrm{~g} \mathrm{P} \mathrm{m}^{-2}, 88 \mathrm{~g} \mathrm{~N} \mathrm{~m}^{-2}\right)$. These treatments were randomly assigned to twelve $1 \mathrm{~m}$ diameter circular plots located along 2 parallel lines in a homogeneous seagrass meadow of equal water depth. In April 1994, sites were marked and fertiliser was applied by spreading it evenly over the plot and mixing it with the surface sediment until only a few pellets were visible. In September 1994, each plot had the surface sediment removed by gently creating a water current by hand motion over the sediment until the rhizomes were visible. Terminal shoots were tagged and the relevant fertiliser pellets were added. Five to $10 \mathrm{~mm}$ of sediment was then added to recover the rhizomes and fertiliser. The seagrass was collected after $80 \mathrm{~d}$ of growth in November 1994. This method of fertilising was used as it increases the nutrient avallability in the sediments and water column adjacent to the seagrass (Udy \& Dennison 1997a, Jones 1999). It also simulates the effect of chronic adsorbed nutrient supply to seagrass meadows, the most likely source of nutrients to effect the mid to outer GBR (Furnas et al. 1988, Mitchell et al. 1996, Steven et al. 1996).

Sediment nutrients: Nutrient pools for both the porewater and adsorbed sediment nutrients were determined at the end of the experiment (Nov 1994). A sipper, constructed of an external PVC pipe and an inner $10 \mu \mathrm{m}$ screen (Udy \& Dennison 1996), was inserted into the sediment to a depth of $10 \mathrm{~cm}$ to collect in situ porewater samples. Porewater samples were collected in acid washed, $\mathrm{N}_{2}$ purged, evacuated serum bottles, immediately placed on ice and frozen within $4 \mathrm{~h}$ of sampling. Samples were later analysed colorimetrically for $\left[\mathrm{NH}_{4}{ }^{+}\right]$and dissolved reactive $\left[\mathrm{PO}_{4}{ }^{3-}\right]$ (Parsons et al. 1989).

Sulfide concentrations in the porewater were also sampled using the sipper, by collecting $6 \mathrm{ml}$ of porewater in acid washed, $\mathrm{N}_{2}$ purged, evacuated serum bottles containing $3 \mathrm{ml}$ of $9 \%$ zinc acetate, which prevents sulfide from being oxidised. The samples were stored at $-4^{\circ} \mathrm{C}$ prior to determining the sulfide concentration colorimetrically (Hines et al. 1989).

One sediment core from each replicate was obtained from the top $10 \mathrm{~cm}$ using syringes $(50 \mathrm{ml})$ with ends removed. Cores were placed on ice and returned to the laboratory within $2 \mathrm{~h}$ for extraction of the adsorbed nutrient fraction. The sediment from each core was mixed into a homogeneous slurry and subsampled for adsorbed $\mathrm{NH}_{4}{ }^{+}$(KCl extraction), adsorbed $\mathrm{PO}_{4}{ }^{3-}$ (Fe strip method) and porosity (see Udy \& Dennison 1996, 1997a).

Biomass, morphology and shoot density. A core of seagrass $(15 \mathrm{~cm}$ diameter) was collected from each replicate plot prior to rhizome tagging (Aug) and at the conclusion of the experiment (Nov) for measurement of seagrass biomass, morphology and shoot density. Seagrass tissue was separated into new leaves (the youngest leaf, plus the bottom section of the second youngest leaf required to make up the equivalent of 1 full size leaf), old leaves (all other leaf tissue), rhizomes and roots, dried $\left(60^{\circ} \mathrm{C}\right.$ for $\left.3 \mathrm{~d}\right)$ and weighed. The longest 5 leaves and roots in every core were measured to estimate the seagrass canopy height and maximal root length. The number of shoots in every core were counted to obtain a measure of shoot density.

Growth rates. Ten Halodule uninervis shoots in each plot were rhizome tagged (Dennison 1990a) in August and most were recovered in November. Leaf growth per shoot was calculated by multiplying the number of leaf scars produced since the rhizome was tagged ( $80 \mathrm{~d}$ ) by the average leaf weight of each treatment (November biomass). The rhizome and root growth was counted as all biomass between the growing tip and the rhizome tag. These growth rates were converted to areal growth $\left(\mathrm{g} \mathrm{m}^{-2} \mathrm{~d}^{-1}\right)$ using the average number of shoots $\mathrm{m}^{-2}$ in the August and November biomass samples. Control and $+\mathrm{P}$ shoot densities were not significantly different $(p>0.05)$ so values from both treatments were pooled. However, the shoot density in the $+\mathrm{N}$ and $\mathrm{N}+\mathrm{P}$ treatments were significantly $(\mathrm{p}<$ 0.05 ) higher than the other treatments, so the shoot densities of these treatments were used separately to convert $g$ shoot ${ }^{-1} \mathrm{~d}^{-1}$ to $\mathrm{g} \mathrm{m}^{-2} \mathrm{~d}^{-1}$.

Due to high sedimentation rates at the mixed Syringodium isoetifolium and Halodule uninervis bed between August and November, the rhizome tags were lost and $S$. isoetifolium growth was estimated in November by a modification of the leaf hole punching technique (Dennison 1990b). Twenty leaves in each replicate were cut 1 to $2 \mathrm{~cm}$ above where the newest leaf emerged from the leaf sheath. These leaves were then allowed to grow for $8 \mathrm{~d}$ prior to collection. New growth was measured as all leaf material above the cut on the oldest non-growing leaf. Leaf growth as $\mathrm{mg}$ shoot ${ }^{-1} \mathrm{~d}^{-1}$ was converted to $\mathrm{g} \mathrm{m}^{-2} \mathrm{~d}^{-1}$ using the shoot density in the November biomass.

Tissue nutrient content and isotopic analysis. Biomass samples were ground to a fine powder in a vibratory ball mill (Retsch MM-2, Haan, Germany). Subsamples were then used for determination of tissue nutrient content and $\delta^{15} \mathrm{~N}$. The percent nitrogen $(\mathrm{N})$ and phosphorus (P) in the tissue parts were determined for new leaves, rhizomes and roots by digesting 
$200 \mathrm{mg}$ of dry ground tissue using a Kjeldahl digest (Oweczkin \& Kerven 1987) and analysing the samples on a Chemlab Mark I autoanalyser for $\mathrm{N}$ as $\mathrm{NH}_{4}{ }^{+}$and $\mathrm{P}$ as $\mathrm{PO}_{4}{ }^{3-}$. For new leaf tissue, $\delta^{15} \mathrm{~N}$ and $\% \mathrm{~N}$ were also determined by automated combustion and analysed on a continuous-flow isotope ratio mass spectrometer ( $\mathrm{CF}$ IRMS, Tracer Mass, Europa Scientific, Crewe, UK).

Amino acid analysis. Fresh leaf tissue was collected at the conclusion of the experiment (Nov) for amino acid analysis. As with the tissue nutrients, leaf tissue was separated into new and old leaves with only the new leaves being used in the analysis. Leaves were finely chopped with a razor blade, then added to methanol in a 10:1 methanol:tissue wet wt ratio. Samples were left for 24 to $48 \mathrm{~h}$ at room temperature and then frozen at $-4^{\circ} \mathrm{C}$ until analysed on a Beckman 6300 High Performance Amino Acid Analyser.

Statistics. Two-way analysis of variances were performed on nutrient and seagrass data to test for significant main effects $( \pm N$ and $\pm P$ ) and interactions between $N$ and $P$. If significant differences were identified, then Tukey's pairwise comparisons were performed to identify which means were significantly different. Interstitial and adsorbed nutrient concentrations of the sediment were analysed after natural log transforming the data, to reduce the variance in the data from fertilised sites. A Kruskal-Wallis test was performed on $\delta^{15} \mathrm{~N}$ values due to the data being nonparametric. Significance was determined at $p<0.05$.

\section{RESULTS}

\section{Mapping}

From interpretation of aerial photos, high density seagrass habitat was first discernible in 1936 and 1946 as a narrow fringe near the cay. It first appeared to expand in the back-reef area NW of Green Island in the 1950 s as a small patch covering approximately 1.1 \pm 0.3 ha in 1959 , and has increased continuously since the 1950 s to $6.5 \pm 1.3$ ha in 1972 and $22.5 \pm 1.7$ ha in 1994 (Figs. 2 \& 3).

In spring 1994 Halodule uninervis (average aboveground biomass, all sites pooled, $16.61 \pm 1.4 \mathrm{~g} \mathrm{dw} \mathrm{m}^{-2}$ ) was the dominant species in this meadow accounting for $45 \%$ of the total biomass. Cymodocea rotundata was the next most common species $(3.95 \pm 1.6 \mathrm{~g} \mathrm{dw}$ $\mathrm{m}^{-2}$ ), with $C$. serrulata and Syringodium isoetifolium occurring in small patches of the meadow $(4.12 \pm 0.7 \mathrm{~g}$ $\left.\mathrm{dw} \mathrm{m}^{-2}\right)$. H. ovalis $\left(0.91 \pm 0.3 \mathrm{~g} \mathrm{dw} \mathrm{m}^{-2}\right)$ occurred intermixed with $H$. uninervis beyond the intertidal and subtidal edges of the main meadow. Halophila species occurred in patches on sandy areas of the back-reef slope down to $20 \mathrm{~m}$ and Thalassia hemprichii was the most uncommon species in the meadow $\left(0.03 \pm 0.02 \mathrm{~g} \mathrm{dw} \mathrm{m}^{-2}\right)$.

\section{Sediment nutrients}

The sediment at the 2 experimental sites was predominantly calcium carbonate (78 to $84 \%$ ), with the ambient nutrient concentrations in the porewater being highly variable $\left(\mathrm{NH}_{4}{ }^{+}\right.$concentrations ranged from 0.3 to $34.0 \mu \mathrm{M}$ and $\mathrm{PO}_{4}{ }^{3-}$ concentrations between 0.6 and $1.7 \mu \mathrm{M})$. The adsorbed nutrient concentrations tended to be less variable, with concentrations of $\mathrm{NH}_{4}{ }^{+}$ between 65 and $183 \mu \mathrm{mol} \mathrm{l}{ }^{-1}$ sed and $\mathrm{PO}_{4}{ }^{3-}$ between 255 and $467 \mathrm{~mol} \mathrm{l}^{-1}$ sed. The use of slow release fertiliser to enrich the sediment nutrients resulted in large and significant $(p<0.01)$ increases in the nutrient concentrations of all experimental plots (Table 1). Increases occurred both in interstitial nutrient concentrations ( $\left[\mathrm{NH}_{4}{ }^{+}\right]$increased 100-fold; $\left[\mathrm{PO}_{4}{ }^{3-}\right]$ increased 20-fold) and in adsorbed nutrient concentrations $\left(\left[\mathrm{NH}_{4}{ }^{+}\right]\right.$in-

Table 1. Concentration of interstitial and adsorbed sediment nutrients in 2 seagrass meadows: one dominated by Halodule uninervis and a mixed seagrass meadow of Syringodium isoetifolium and $H$. uninervis. Nitrogen as $\mathrm{NH}_{4}{ }^{+}$, phosphorus as $\mathrm{PO}_{4}{ }^{3-}$ and sulfide as $S^{2-}$ in the treatments: control (C), phosphorus added $(+P)$, nitrogen added $(+N)$ and nitrogen plus phosphorus added $(\mathrm{N}+\mathrm{P})$. 'Significant difference at $\mathrm{p}<0.05,{ }^{\prime} \cdot$ significant difference at $\mathrm{p}<0.01, \cdots$ significant difference at $\mathrm{p}<0.001$

\begin{tabular}{|c|c|c|c|c|c|c|c|}
\hline & \multirow[t]{2}{*}{ C } & \multirow[t]{2}{*}{$+P$} & \multirow[t]{2}{*}{$+\mathrm{N}$} & \multirow[t]{2}{*}{$\mathrm{N}+\mathrm{P}$} & \multicolumn{3}{|c|}{$F$ values of main effects } \\
\hline & & & & & $\mathrm{P}$ & $N$ & Site \\
\hline \multicolumn{8}{|l|}{ Interstitial nutrients } \\
\hline$\left[\mathrm{NH}_{4}^{+}\right](\mu \mathrm{M})^{a}$ & $6.2(2.2)$ & $5.0(1.1)$ & $528(204)$ & $257(138)$ & 1.7 & $43.3 \cdots$ & 0.2 \\
\hline$\left[\mathrm{PO}_{4}^{3-}\right](\mu \mathrm{M})^{\mathrm{a}}$ & $1.1(0.1)$ & $18(7)$ & $1.0(0.2)$ & $15(7)$ & $25.8 \cdots$ & 1.0 & 2.4 \\
\hline$\left[S^{2-}\right](\mu \mathrm{M})$ & $41(14)$ & $36(11)$ & $17(10)$ & $25(13)$ & 0.3 & 2.1 & $11.2 \cdots$ \\
\hline \multicolumn{8}{|l|}{ Adsorbed nutrients } \\
\hline$\left[\mathrm{NH}_{4}^{+}\right]\left(\mu \mathrm{mol} \mathrm{I}^{-1}{ }_{\mathrm{sed}}\right)^{\mathrm{a}}$ & $94(18)$ & $91(7)$ & $5546(3366)$ & $4364(2267)$ & 0.5 & $77.1 \cdots$ & $19.6^{\prime}$ \\
\hline$\left[\mathrm{PO}_{4}{ }^{3-}\right]\left(\mu \mathrm{mol} \mathrm{l}{ }^{1}{ }_{\mathrm{sed}}\right)^{\mathrm{a}}$ & $364(29)$ & $1297(564)$ & $438(49)$ & $1735(846)$ & $12.9^{\cdots}$ & 0.4 & 0.7 \\
\hline
\end{tabular}





Fig. 3. Series of aerial photos showing the expansion of the seagrass meadow in the subtidal lagoon on the NE side of Green Island from 1936 until 1994 
creased 10 - to 100 -fold $\left[\mathrm{PO}_{4}{ }^{3-}\right]$ increased 2 - to 10 -fold). The sulfide concentration in the interstitial water was highly variable and did not show a significant effect due to the nutrient treatments, with values ranging from 0.1 to $129 \mu \mathrm{M}$.

Dissolved $\mathrm{NH}_{4}{ }^{+}, \mathrm{PO}_{4}{ }^{3-}$, and adsorbed $\mathrm{PO}_{4}{ }^{3-}$ concentrations were not significantly affected by the site, however, the dissolved sulfide was significantly lower and adsorbed $\mathrm{NH}_{4}^{+}$was significantly higher in the Syringodium isoetifolium/Halodule uninervis mixed bed compared to the site where $H$. uninervis was the dominant species. The difference between sites could be due to differences in the sedimentation rate and disturbance due to boat traffic affecting the hydrology of the porewater or differences in the microbial populations of the sediment due to the different species present.

\section{Biomass, shoot density, canopy height and growth}

\section{Halodule uninervis}

Halodule uninervis leaf biomass, canopy height, shoot density and growth all significantly $(\mathrm{p}<0.01)$ increased in the treatments with added nitrogen ( $+\mathrm{N}$ and $N+P$ ) (Tables $2 \& 3$, Figs. 4 \& 5). Leaf growth in the nitrogen treatments $(+\mathrm{N}$ and $\mathrm{N}+\mathrm{P})$ was 4 times greater than in the control, while the rhizome and root growth increased by 3 - and 2 -fold, respectively. In contrast to



Syringodium isoetifolium

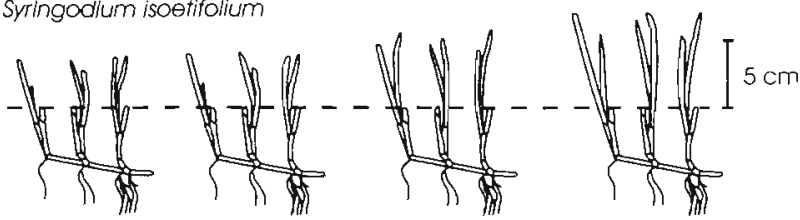

Control $+P \quad+N \quad N+P$

Fig. 4. Growth of Halodule uninervis and Syringodium isoetifolium in the control, phosphorus $(+P)$, nitrogen $(+N)$ and nitrogen plus phosphorus $(\mathrm{N}+\mathrm{P})$ treatments: $H$. uninervis, length of leaves and roots represents the average leaf canopy height and root length, number of shoots represents the mean number of new shoots formed since the rhizomes were tagged ( $80 \mathrm{~d})$ and the rhizome leaf scars are equal to the mean number of leaves produced. $S$. isoetifolium, length of leaves is equal to leaf growth after cutting ( $8 \mathrm{~d}$ ), dotted line represents the location where leaves were cut

the growth response, the rhizome and root biomass was not significantly different $(p>0.05)$ between treatments. This suggests that the microbial decay of roots and rhizomes may be more rapid in the $\mathrm{N}$ treatments. The lack of a significant $(p>0.05$ ) effect of $P$ for any

Table 2. Halodule uninervis and Syringodium isoetifolium. Biomass, growth, tissue nutrient content and $\delta^{15} \mathrm{~N}$ ratios in 2 seagrass species exposed to 4 nutrient treatments: control (C), phosphorus added (+P), nitrogen added (+N) and nitrogen plus phosphorus added $(\mathrm{N}+\mathrm{P})$. Values in brackets are standard errors; $\mathrm{nd}=$ no data




Table 3. Fvalues from 2-way analyses of variance performed on data using presence and absence of $N$ and $P$ as the main effects The interaction term represents the interaction between $N$ and $P$. 'Significant difference at $p<0.05$, $" \cdot$ significant difference at $p<0.01, \cdots$ significant difference at $p<0.001$; nd = no data

\begin{tabular}{|c|c|c|c|c|c|c|}
\hline & \multicolumn{3}{|c|}{ Halodule uninervis } & \multicolumn{3}{|c|}{ Syringodium isoetifolium } \\
\hline & \multicolumn{2}{|c|}{ Main effects } & \multirow[t]{2}{*}{ Interaction } & \multicolumn{2}{|c|}{ Main effects } & \multirow[t]{2}{*}{ Interaction } \\
\hline & $\mathrm{P}$ & $N$ & & $\mathrm{P}$ & $N$ & \\
\hline Density (shoots $\mathrm{m}^{-2}$ ) & 4.5 & $46.2^{\cdots}$ & 1.4 & 3.0 & $8.7^{\circ}$ & $6.7^{*}$ \\
\hline \multicolumn{7}{|l|}{ Biomass $\left(\mathrm{g} \mathrm{m}^{-2}\right)$} \\
\hline Leaves & $12.0^{\cdots}$ & $270.3 \cdots$ & $8.5^{\circ}$ & 0.3 & 1.1 & 5.0 \\
\hline Rhizomes & 0.1 & 0.8 & 0.8 & 1.6 & 0.0 & 0.1 \\
\hline Roots & 0.1 & 0.9 & 1.7 & 0.1 & 4.6 & 0.0 \\
\hline \multicolumn{7}{|c|}{ Growth rate $\left(\mathrm{g} \mathrm{m}^{-2} \mathrm{~d}^{-1}\right)$} \\
\hline Leaves & 0.4 & $47.2 \cdots$ & $17.6^{\cdots}$ & 3.1 & 4.9 & 0.3 \\
\hline Rhizomes & 0.1 & $21.6^{\cdots}$ & $8.5 \cdots$ & nd & nd & nd \\
\hline Roots & 0.3 & $7.7 \cdots$ & $3.1^{\circ}$ & nd & nd & nd \\
\hline \multicolumn{7}{|l|}{ Tissue nutrients } \\
\hline$N(\%)$ Leaves & 0.3 & $19.6^{*}$ & 1.2 & 0.1 & $26.0^{\cdots}$ & 0.2 \\
\hline Rhizomes & 0.0 & $28.0^{\cdots} \cdots$ & 0.1 & 0.0 & $100.3^{\cdots}$ & 8.5 \\
\hline$P(\%) \quad$ Leaves & 1.3 & 4.5 & 2.2 & $7.4^{\circ}$ & $19.0^{\cdots}$ & 0.1 \\
\hline Rhizomes & $22.8^{\cdots}$ & 5.2 & 0.0 & 4.9 & 0.2 & 3.3 \\
\hline$\delta^{15} N(\%)$ Leaves & nd & $9.0^{d \cdot}$ & & nd & $8.3^{\mathrm{a} \cdot}$ & \\
\hline
\end{tabular}
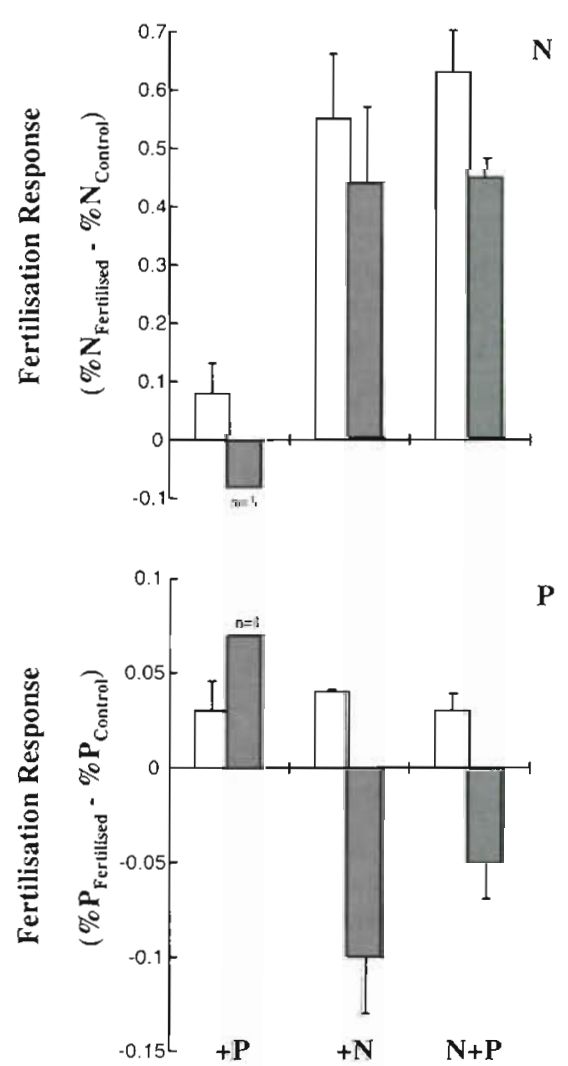

Fertilisation Treatment

$\square$ H. uninervis

S. isoetifolium
Fig. 5. The response of nutrient concentrations in the seagrass leaves to fertilisation with phosphorus $(+P)$, nitrogen $(+N)$ and nitrogen plus phosphorus $(\mathrm{N}+\mathrm{P})$. Zero (0) represents the control concentration for nitrogen $(\% N)$ and phosphorus $(\% \mathrm{P})$. Increases, relative to the control, are positive and decreases are negative Bars represent SE growth parameter indicates that $H$. uninervis was not limited by $\mathrm{P}$ availability. However, there was a significant main effect of $P$ on leaf biomass and significant interactions between $\mathrm{P}$ and $\mathrm{N}$ for leaf biomass and the growth rate of leaves, rhizomes and roots (Table 3 ).

\section{Syringodium isoetifolium}

The biomass and growth rate of Syringodium isoetifolium expressed in $\mathrm{g} \mathrm{m}^{-2}$ was not significantly $(p>0.05)$ increased by either the $\mathrm{N}$ or $\mathrm{P}$ treatments (Tables $2 \& 3$ ). However, the growth per shoot was significantly higher in the $N$ treatments (Fig. 4). In contrast, the shoot density of $S$. isoetifolium decreased, relative to the control, in all the fertilisation treatments (Table 2), with the main effect of $N$ and the interaction being significant $(p<0.05)$. Shoot lengths for $S$. isoetifolium were highly variable between replicates and were not significantly different $(p>0.05)$ between treatments. During the study period this site increased its sediment depth by 30 to $40 \mathrm{~cm}$, probably due to the erosion of the NW corner of Green Island (Fig. 3). This rapid sedimentation resulted in some of the replicate sites not being relocated and may have contributed to the high variability be- 
tween plots and the lack of significant differences between the nutrient treatments.

\section{Tissue nutrient content}

\section{Halodule uninervis}

The $\% \mathrm{~N}$ present in Halodule uninervis leaves and rhizomes was significantly $(p<0.01)$ increased by $N$ additions $(+N$ and $N+P)$ and there was no significant main effect or interaction with $P$ (Fig. 5, Tables $2 \& 3$ ). Although the $\mathrm{N}$ content of roots had the opposite trend, no replication was possible due to the small quantity of biomass requiring replicates to be pooled.

Tissue phosphorus content of Halodule uninervis leaves was not significantly ( $p>0.05$ ) different between any of the treatments (Tables $2 \& 3$ ), while the \%P in the rhizomes was significantly $(p<0.01)$ increased by the addition of $P$ and there was a trend $(p<0.06)$ for $N$ to reduce the \% $P$ in the rhizomes (Tables $2 \& 3$ ).

\section{Syringodium isoetifolium}

Changes in the tissue nitrogen content due to elevated sediment nutrients were similar for Halodule uninervis and Syringodium isoetifolium (Fig. 5), with the leaves and rhizomes of $S$. isoetifolium having significantly $(\mathrm{p}<0.01)$ higher $\% \mathrm{~N}$ in the $\mathrm{N}$ treatments and no significant main effect or interaction with $\mathrm{P}$ ( $\mathrm{p}>$ 0.05 ) (Tables $2 \& 3$ ). The $\% \mathrm{P}$, however, had a significant main effect from both $\mathrm{N}$ and $\mathrm{P}$ additions, with $+\mathrm{P}$ increasing the $\% \mathrm{P}$ and $+\mathrm{N}$ decreasing the $\% \mathrm{P}$. This resulted in the $\% \mathrm{P}$ of leaves from the $\mathrm{N}+\mathrm{P}$ treatment not being significantly different $(p>0.05)$ from the control due to the combination of both main effects (Fig. 5). The \% $\mathrm{P}$ content of the rhizomes did not show a significant effect of any treatment, possibly due to the low replication (Tables $2 \& 3$ ). The tissue nutrient content of $S$. isoetifolium, in all the treatments, was lower in leaves and higher in rhizomes than the equivalent plant portion of $H$. uninervis.

\section{Amino acids}

Halodule uninervis had 3 times the total amino acid content of Syringodium isoetifolium, which was due primarily to a large proline content in H. uninervis $(69$ to $81 \%$; Fig. 6). With the exception of proline, the amino acid content in the leaves of the 2 species responded in a similar manner to the fertilisation treatments. The control and $+\mathrm{P}$ treatment were not significantly different $(p>0.05)$ with the combined



Fig. 6. Amino acid concentrations in the seagrass leaves exposed to different fertilisation treatments; control (C), phosphorus $(+P)$, nitrogen $(+N)$, nitrogen plus phosphorus $(N+P)$. Proline (Pro) has 1 amine group (1N) while both glutamine (Gln) and asparagine (Asn) have $2(2 \mathrm{~N})$. Other amino acids (aa) make up less than $50 \%$ of the total amino acid pool in both species

concentration of asparagine and glutamine being 1.8 $\pm 0.4 \mu \mathrm{mol} \mathrm{g}{ }^{-1}$ iresh w1 in $H$. uninervis and $<0.1 \mu \mathrm{mol}$ $\mathrm{g}^{-1}$ iresh wt in $S$. isoetifolium. When $\mathrm{N}$ was added $(+\mathrm{N}$ and $\mathrm{N}+\mathrm{P}$ ), an increase in glutamine and asparagine concentrations of 3 -fold occurred in $H$. uninervis leaves $\left(2.9 \pm 1.1 \mu \mathrm{mol} \mathrm{g}^{-1}{ }_{\text {fresh wt }}\right)$ and an increase of 100 -fold occurred in the $S$. isoetifolium leaves $(2.7 \pm$ $1.2)$. There was no significant $(p>0.05)$ increase in the concentration of other amino acids in $H$. uninervis (all treatments $1.6 \pm 0.3 \mathrm{\mu mol} \mathrm{g}^{-1}$ tresh wt); however, $S$. isoetifolium demonstrated a 2 -fold increase in the concentration of 'other amino acids' with the addition of $\mathrm{N}$ (control and $+\mathrm{P} 0.5 \pm 0.1 \mu \mathrm{mol} \mathrm{g}^{-1}$ fresh wi $+\mathrm{N}$ and $\mathrm{N}+\mathrm{P} 1.1 \pm 0.3 \mu \mathrm{mol} \mathrm{g}^{-1}$ fresh wt).

$$
\delta^{15} \mathrm{~N}
$$

Seagrass leaf material from the control and $+\mathrm{P}$ treatmen: had $\delta^{15} \mathrm{~N}$ values between 1.1 and $1.7 \%$. The $\delta^{15} \mathrm{~N}$ values of the seagrass in the $+\mathrm{N}$ and $\mathrm{N}+\mathrm{P}$ treatments were more negative than the $\delta^{15} \mathrm{~N}$ of the fertiliser $(0 \%$ ) in most samples and had higher variation between replicates than the control or $+\mathrm{P}$ plants, with values between 0.2 and $-7.3 \%$ (Table 2 ). 


\section{DISCUSSION}

\section{Expansion of seagrass meadow}

Observations of changes in seagrass abundance at Green Island reef allows inferences on historical events, which may have influenced seagrass growth, to be made. Oblique photographs from 1936 and 1946 show very little evidence of dense seagrass habitat to the northwest of Green Island, but photographs from the late 1950s (Kuchler 1982) clearly show the first dense seagrass habitat in this area. By 1972, a dense seagrass meadow of $6.5 \pm 1.3 \mathrm{ha}$, consisting predominantly of Halodule uninervis, Cymodocea serrulata and Halophila ovalis, was well established in this area (Kuchler 1978, current study). The expansion of seagrass habitat before the sewage pipe was installed indicates that increased nutrient availability associated with the reef crest sewage outfall in 1972 was not a primary cause for this expansion in seagrass distribution at Green Island. This suggests that other factors including water seepage and nutrient translocation from the cay as well as regional changes in nutrient availability in GBR waters may have caused the observed expansion prior to 1972 . The continued expansion of the seagrass meadow after 1972 may have been influenced by the sewage discharge in addition to regional changes in nutrient availability.

Between 1952 and 1974 the area of sugarcane in the Cairns region increased from 53403 to 91040 ha (Australian Bureau of Statistics, cited in Hopley 1988). This $70 \%$ increase in sugarcane and its accompanying increases in fertiliser application would have increased $\mathrm{N}$ input by rivers to the GBR 'lagoon'. Increased rates of erosion associated with land clearing practices would have also increased the nutrient load delivered to the GBR adsorbed to sediment particles by approximately $400 \%$ (Moss et al. 1996). Prior to 1972, an underground septic system and the daily disposal of food waste into Green Island waters could have contributed to nutrient enrichment and the initial increases in seagrass distribution. Since 1972, large increases in visitation rates and the use of a sewage outfall may have enhanced nutrient availability near Green Island and could have changed the primary limiting nutrient from $\mathrm{P}$ to $\mathrm{N}$. However, at the time of sampling, it is unlikely that sewage provided the major $\mathrm{N}$ source for seagrasses on the Green Island reef. Leaf tissue $\delta^{15} \mathrm{~N}$ values ranged from 1.3 to $1.7 \%$, suggesting that their primary $\mathrm{N}$ source comes from either fertilisers or $N_{2}$ fixation (Udy \& Dennison 1997a). If their primary $N$ source was from sewage, the seagrass would be expected to have leaf tissue $\delta^{15} \mathrm{~N}$ values closer to 10 (Grice et al. 1996, Udy \& Dennison 1997b). It is possible that $\delta^{15} \mathrm{~N}$ values were higher prior to the cessation of raw sewage discharge in 1992. However, due to internal recycling of $\mathrm{N}$ in the seagrass, $\delta^{15} \mathrm{~N}$ values tend to be highly conservative (Grice et al. 1996), suggesting that the contribution of sewage $\mathrm{N}$ to the Green Island seagrass has been minimal.

The pattern of gradual increase in seagrass distribution observed at Green Island since the 1950s suggests that the most likely causal factor has been an increase in nutrient availability due to anthropogenic activity in this region of the GBR. However, it is also important to consider other possible causes, such as disturbance by cyclones, changes in the grazing pressure and other environmental changes. Firstly, the last major cyclone to affect this section of coast occurred in 1927 (Bureau of Meteorology, Brisbane), prior to the first aerial photograph. If the observed seagrass expansion was due to recovery from the 1927 cyclone, this suggests that there was approximately $20 \mathrm{yr}$ with no recovery, followed by 20 yr of gradual recovery and a further $20 \mathrm{yr}$ of rapid recovery. However, this is not consistent with observations from the Gulf of Carpentaria, Australia, where Halodule uninervis recovered within 5 yr of a major cyclone (Poiner et al. 1993). A second possibility is that a reduction in grazing pressure may have allowed the expansion of seagrass at Green Island. The authors consider this is unlikely as there is no evidence that extensive grazing of seagrass is occurring as observed by McGlathery (1995), in Bermuda, and most herbivorous fish feed on turf algae or the epiphytic algae on the seagrass leaves rather than the seagrass itself (Hixon 1997, McClanahan 1997). Green Island has also been identified as having a more diverse fish population than neighbouring coral atolls (Baxter 1990), suggesting that there has not been a large decline in herbivorous fish species, which would be necessary to explain the large expansion in the distribution of seagrass. A third possibility, suggested by Kuchler (1978), is that a reduction in the sediment grain size due to a beach replenishment program in the 1970 s may have contributed to the increase in seagrass distribution. Although it is possible that finer sediment may have facilitated seagrass growth in the 1970 s this is clearly not the primary cause for the seagrass expansion as the aerial photographs clearly show that the expansion began prior to the 1970 s.

\section{Sediment nutrients}

Ambient porewater $\mathrm{PO}_{4}{ }^{3-}$ concentrations in carbonate sediments of Green Island ( 0.9 to $1.3 \mu \mathrm{M})$ were similar to values reported from seagrass beds in the Bahamas (1.5 $\mu \mathrm{M}_{\text {; }}$ Short et al. 1985) and Florida Bay, USA (0.5 to $3 \mu \mathrm{M}$; Fourqurean et al. 1992b). Stimulation of seagrass growth by $\mathrm{P}$ addition and changes in 
the C:N:P ratio of seagrass leaves indicated that $P$ was the primary limiting nutrient for seagrass growth at the Bahamas and Florida Bay study sites, which had N:P ratios in their porewater of $67: 1$ and 93-232:1, respectively (Short et al. 1990, Fourqurean et al. 1992a). The low porewater $\mathrm{PO}_{4}{ }^{3-}$ concentration in the current study would suggest that $\mathrm{P}$ could also limit seagrass growth at Green Island. However, the low $\mathrm{NH}_{4}{ }^{+}$concentrations and a N:P ratio of $6: 1$ in the porewater, well below the N:P ratio required for seagrass growth of 19:1 (this study), suggests that seagrass growth is limited by the availability of $\mathrm{N}$ rather than $\mathrm{P}$ (Table 4).

Ambient concentrations of adsorbed $\mathrm{NH}_{4}{ }^{+}$(74 to $114 \mathrm{\mu mol} \mathrm{l}^{-1}{ }_{\text {sed }}$ ) were higher at Green Island than in the siliceous sediment of Moreton Bay, Southeast Queensland $\left(48 \mu \mathrm{mol} \mathrm{l}^{-1}{ }_{\text {sed }}\right.$ ), where $\mathrm{N}$ has been demonstrated to limit seagrass growth (Udy \& Dennison 1997a). Bioavailable $\mathrm{P}$, measured using the Fe strip method, was less at Green Island (311 to $415 \mu \mathrm{mol} \mathrm{l^{-1 }}$ sed) compared with Moreton Bay (492 $\mathrm{mol} \mathrm{I}^{-1}$ sed; Udy \& Dennison 1996, 1997 a). However, the N:P ratio for adsorbed nutrients at Green Island of 1:4 still suggests that the availability of $N$ is more likely to limit seagrass growth than the availability of $P$.

\section{Seagrass response to elevated sediment nutrients}

The responses of Halodule uninervis and Syringodium isoetifolium to fertilisation indicate $\mathrm{N}$ is the primary limiting nutrient for seagrass growth at Green Island, with $H$. uninervis demonstrating 'exclusive $\mathrm{N}$ limitation' and S. isoetifolium 'primary $N$ limitation' with secondary $\mathrm{P}$ limitation (defined in Fisher \& Butt 1994, Udy \& Dennison 1997a). Nitrogen limitation of H. uninervis (Udy \& Dennison 1997a) and other seagrass species have been reported previously from sites with siliceous sediment (Bulthius et al. 1992, Kenworthy \& Fonseca 1992, Short et al. 1993). However, N limitation of seagrass growth in carbonate sediment has not been experimentally demonstrated previously. However, Agawin et al. (1996) suggest, based on tissue nutrient content, that $\mathrm{N}$ is the primary limiting nutrient for Enhalus acoroides growth in carbonate sediments of the NW Philippines. The N content in new H. uninervis leaves from the control and $+\mathrm{P}$ treatment $(2.4 \% \mathrm{~N})$ were higher than the $1.8 \% \mathrm{~N}$ suggested by Duarte (1990) to represent $N$ limitation, yet the same as found in new $H$. uninervis leaves from Moreton Bay $(2.4 \% \mathrm{~N}$ ) which were $\mathrm{N}$ limited (Udy \& Dennison 1997 ). While, the $N$ content of new $S$. isoetifolium leaves was below the $1.8 \% \mathrm{~N}$ critical level (Duarte 1990 ) and $0.8 \%$ lower than $H$. uninervis, yet both species demonstrated similar increases in $\mathrm{N}$ content when fertilised with $\mathrm{N}(0.5$ to $0.6 \% \mathrm{~N})$. This contrast in the $\mathrm{N}$ content of $H$. uninervis and $S$. isoetifolium leaves, yet similar fertilisation response is probably due to species-specific variation in the critical levels of $\mathrm{N}$ which represent nutrient limitation, as previously observed (Udy \& Dennison 1997a). It is also important to note that the $\% \mathrm{~N}$ in new leaves (used in the current study) would be expected to be higher than the $\% \mathrm{~N}$ of the total leaves used in the Duarte (1990) study (Penderson \& Borum 1992, Penderson et al. 1997, Udy unpubl. data for Zostera capricorni).

Duarte (1990) also found that a P content of leaves less than $0.2 \% \mathrm{P}$ corresponded to $\mathrm{P}$ limitation of seagrass growth. In the current study the P content of new leaves from Halodule uninervis and Syringodium isoetifolium was above $0.2 \% \mathrm{P}$ in all samples, except $S$. isoetifolium $+\mathrm{N}$ and $\mathrm{N}+\mathrm{P}$ treatments. In conjunction with the seagrass growth responses this suggests $P$ secondarily limits $S$. isoetifolium growth, but not $H$. uninervis growth. The only characteristic of $H$. uni-

Table 4. Comparison of porewater nutrient concentrations from various locations worldwide. $\mathrm{N}=\mathrm{N}$ limitation of seagrass growth; $\mathrm{P}=\mathrm{P}$ limitation of seagrass growth; no limit $=$ no limitation of seagrass growth

\begin{tabular}{|c|c|c|c|c|c|c|}
\hline Location & $\begin{array}{l}\text { Sediment } \\
\text { type }\end{array}$ & $\begin{array}{c}\text { Porewater } \mathrm{r} \\
{\left[\mathrm{NH}_{4}{ }^{+}\right]} \\
(\mu \mathrm{M})\end{array}$ & $\begin{array}{c}\text { nutrients } \\
{\left[\mathrm{PO}_{4}{ }^{3-}\right]} \\
(\mu \mathrm{M})\end{array}$ & $\begin{array}{l}N: P \\
\text { ratio }\end{array}$ & $\begin{array}{c}\text { Primary } \\
\text { nutrient } \\
\text { limitation }\end{array}$ & Source \\
\hline Green Island, Qld, Aust. & Carbonate & 5.6 & 1.3 & 4.3 & $N$ & This study \\
\hline San Salvador ls., Bahamas & Carbonate & 100 & 1.5 & 67 & $\mathrm{P}$ & Short et al. $(1985,1990)$ \\
\hline Florida, USA & Carbonate & 98 & $0.5-3$ & $93-232$ & $P$ & Fourqurean et al. (1992b) \\
\hline Rottnest Island, WA, Aust. & Carbonate & 9.2 & 2.0 & 4.6 & No limit & Udy \& Dennison (1999) \\
\hline S. Sulawesi, Indonesia & Carbonate & 107 & 6 & 18 & No limit & Eiftemeijer et al. (1994) \\
\hline Moreton Bay, Qld, Aust. & Siliceous & 7.1 & 4.7 & 1.5 & $\mathrm{~N}$ & Udy \& Dennison (1997a) \\
\hline Victoria, Aust. & Siliceous & $11-19$ & $6-8$ & 2 & $\mathrm{~N}$ & Bulthius et al. (1992) \\
\hline Netherlands & Siliceous & $20-50$ & - & - & $\mathrm{N}$ & van Lent et al. (1995) \\
\hline Alaska, USA & Siliceous & $30-130$ & $6-25$ & 5 & $\mathrm{~N}$ & Short (1983) \\
\hline S. Sulawesi, Indonesia & Siliceous & 60 & 10 & 6 & No limit & Eiftemeijer et al. (1994) \\
\hline Victoria, Aust. & Siliceous & $200-1700$ & $3-60$ & 67 & No limit & Bulthius \& Woelkerling (1981) \\
\hline
\end{tabular}


nervis which was significantly higher in the $\mathrm{N}+\mathrm{P}$ treatment relative to the $+N$ treatment was leaf canopy height and biomass, suggesting that $\mathrm{P}$ availability may secondarily limit some characteristics of $H$. uninervis.

As seagrasses at Green Island demonstrated primarily $\mathrm{N}$-limited growth responses, we can assume their demand for $\mathrm{P}$ and micronutrients, such as iron, is saturated under ambient nutrient conditions. This contrasts with previous studies which suggest that the availability of $\mathrm{P}$ or iron is most likely to limit seagrass growth in carbonate environments (Entsch et al. 1983, Short et al. 1990, Fourqurean et al. 1992a, Duarte et al. 1995). It is possible that anthropogenic factors and/or characteristics of Australian soils influence the relative importance of different nutrients to seagrasses and result in $\mathrm{N}$ limitation rather than $\mathrm{P}$ or Fe limitation.

The availability of $P$ relative to $N$ in Green Island sediments may have increased during the last $50 \mathrm{yr}$ due to tourist activities on the island and changes in mainland land use practices. Van Woesik (1990) demonstrated that water circulation patterns around Green Island caused water and suspended particles from the sewage outfall to accumulate in the NW region, where the major seagrass accumulation has occurred. Sewage loads may also have altered the limiting nutrient for seagrass growth at Green Island from $\mathrm{P}$ to $\mathrm{N}$ limitation as sewage often has a low $\mathrm{N}$ :P ratio (Howarth 1988). Changes in land use on the mainland have also increased the nutrients supplied by rivers to the GBR lagoon and may be resulting in wide spread eutrophication of the inner reefs (Kinsey 1991, Bell 1992). Furnas et al. (1995) estimated that $1947 \mathrm{t} \mathrm{N} \mathrm{yr}^{-1}$ and $193{\text { t } P ~ y^{-1}}^{-1}$ are delivered by rivers (Daintree and Barron) to the Cairns region (Cape Tribulation to Cape Grafton) of the GBR 'lagoon' as dissolved and adsorbed nutrients, a 100 to $500 \%$ increase on nutrients delivered to this region by rivers prior to agricultural and urban development. Most of the adsorbed nutrients settle within $10 \mathrm{~km}$ of the coast (Larcombe \& Woolfe 1995); however, storms and cyclones resuspend deposited sediment and can produce sediment plumes extending more than $30 \mathrm{~km}$ from the coast (Gagan et al. 1990). Recent river plumes generated by cyclones 'Sadie' (1994) and 'Violet' (1995) have reached beyond Green Island (Steven et al. 1996), demonstrating that terrigenous sediment and nutrients have the potential to reach Green Island.

The current study has estimated that $280 \mathrm{~kg} \mathrm{~N}^{-1}$ $\mathrm{yr}^{-1}$ and $24 \mathrm{~kg} \mathrm{P} \mathrm{ha} \mathrm{yr}^{-1} \mathrm{rr}^{-1}$ are required to support the measured rates of growth and tissue nutrient content in the dense seagrass bed on the NW side of Green Island. If we assume the nutrients delivered by rivers (estimated by Furnas et al. 1995) are evenly distributed across the 'Cairns Box' (described by Furnas et al. 1995) this results in $3.3 \mathrm{~kg} \mathrm{~N} \mathrm{ha}^{-1} \mathrm{yr}^{-1}$ and $0.3 \mathrm{~kg} \mathrm{P} \mathrm{ha}^{-1}$ $\mathrm{yr}^{-1}$ being contributed by riverine input. This would supply $-1.5 \%$ of the nutrients turned over each year in the seagrass bed NW of Green Island. As the seagrass nutrient requirements can be met by nutrient recycling, $\mathrm{N}_{2}$ fixation and external supply, it is possible that the continuous and increasing addition of nutrients by rivers to the Cairns region of the GBR 'lagoon' over the past 50 yr could have provided sufficient nutrients to sustain the gradual increase in seagrass distribution which has been observed. If nutrients derived from mainland catchments are influencing Green Island it is likely that the N:P ratio of nutrients reaching the island will be lower than that of the riverine discharge and hence favour $\mathrm{N}$ limitation of the seagrass at Green Island. Since $\mathrm{NO}_{3}{ }^{-}$and $\mathrm{NH}_{4}{ }^{+}$are more soluble than $\mathrm{PO}_{4}{ }^{3-}$, the $\mathrm{N}$ fraction would dissolve in the water column and most likely be assimilated by phytoplankton and algae before reaching Green Island. However, the $\mathrm{PO}_{4}{ }^{3-}$ fraction is more likely to remain adsorbed to the sediment particles and be transported during major storm events to Green Island.

Micronutrient bioavailability in Green Island sediment may have also been elevated by local and/or regional sources. The iron present in water and sediment would chelate with the increased organics from resort waste (sewage and food scraps), hence, increasing their bioavailability (Howarth \& Marino 1988). Regionally, it is likely that changes in land use on the mainland have resulted in increased erosion and hence higher supply rates of iron-rich sediment to the GBR lagoon.

Alternatively, the observed $N$ limitation of seagrasses at Green Island may not be due to anthropogenic impacts and may represent a typical Australian phenomenon. This is supported by $\mathrm{PO}_{4}{ }^{3-}$ concentrations in the GBR 'lagoon' (0.16 to $0.21 \mu \mathrm{M})$ being much higher than in other reefal environments, such as the Caribbean $(0.03 \mu \mathrm{M})$ (Baldwin 1992, Furnas et al. 1988), where $P$ limitation of seagrass growth has been demonstrated (Short et al. 1990). Nitrogen limitation has also been demonstrated, using fertilisation experiments, in the marine carbonate environment of Rottnest Island, Western Australia (Udy \& Dennison 1999) and is suggested to dominate Australian freshwater ecosystems (Harris 1996). However, marine carbonate environments and freshwater environments elsewhere in the world are usually $\mathrm{P}$ limited (Smith 1984, Short et al. 1990, Fourqurean et al. 1992a). Nitrogen fixation requires large inputs of fixed carbon for energy and is inhibited by the presence of available $\mathrm{N}$ in the environment. Hence, high $\mathrm{N}_{2}$ fixation rates suggest high $\mathrm{N}$ demand in a low- $\mathrm{N}$ environment (Capone 1983). Vegetated marine sediments in Australia have $\mathrm{N}_{2}$ fixation rates 10 to 100 times higher than in similar environments worldwide (Alongi et al. 1992, Perry \& 
Dennison unpubl.), suggesting that $N$ availability is very low in Australian mangrove and seagrass environments.

Increased nutrient supplies to the coastal zone has often led indirectly to seagrass decline through reduced light availability due to increased epiphyte, phytoplankton and macroalgal growth (Orth \& Moore 1983, Cambridge \& McComb 1984, Silberstein et al. 1986, Abal \& Dennison 1996). However, at Green Island, increases in local and/or regional nutrient availability have led to increases in seagrass biomass and distribution. Seagrass declines have historically occurred in regions where large seagrass communities occurred prior to anthropogenic elevation of nutrients and therefore where the 'pre-anthropogenic impact' nutrient availability was likely to already be relatively high. Hence, increases in nutrient availability due to anthropogenic inputs were sufficient to change the ecosystem to a phytoplankton/algal dominated system (Duarte 1995), resulting in seagrass decline due to light limitation (Tomasko \& Lapointe 1991, Short et al. 1995, Taylor et al. 1995). In contrast, we hypothesise that Green Island had insufficient nutrients to support an extensive seagrass meadow prior to anthropogenic increases in nutrient availability. Hence, the addition of nutrients from sewage, organic waste and/or regional sources has resulted in sufficient nutrients to establish and sustain an extensive seagrass meadow. Increases in seagrass biomass and distribution due to anthropogenic nutrient inputs have also been suggested at other locations in the GBR. Klumpp et al. (1997) have suggested that the dense seagrass beds surrounding the sewage pipe at Great Palm Island are a result of increased local nutrient availability. While increases in seagrass at Low Isles, which has no significant nutrient point source, could result from increases in regional nutrient availability. The combination of these studies and observations suggest that increases in nutrient availability can have both a negative and positive effect on seagrass biomass and growth. In turbid estuarine water, where light availability generally limits seagrass growth, increases in nutrient availability are expected to result in a decline in seagrass growth and/or biomass. While in clear oligotrophic water where light is not limiting seagrass growth it is possible that an increase in nutrient availability could cause an increase in seagrass growth and biomass.

Seagrasses are an important ecosystem in Australia's GBR region, covering well over $4000 \mathrm{~km}^{2}$ of coastal, reef and inter-reef habitat (Lee Long et al. 1993, 1997). Seagrass is more common in the northern GBR than in the southern GBR, which supports little or no seagrass on its coral reefs (pers. obs.). The reefs of the southern GBR receive less fluvial nutrients than the northern GBR, as rainfall and erosion rates are less (Rose 1993) and reefs are more distant from the mainland. These factors reduce the rate of nutrient supply, which in turn, limits the nutrient availability to seagrass on the southern cays and restricts the seagrass distribution to a few sparse patches at the base of the reef slope (pers. obs.).

In conclusion, the evidence from historical aerial photos confirms a rapid and many-fold increase in abundance and distribution of seagrasses at Green Island since the expansion of human influences. The increases of dense seagrass habitat at Green Island have occurred over a period of rapid increases in anthropogenic nutrient impacts both locally and regionally. We have established that the growth of seagrass at Green Island is primarily limited by the availability of $\mathrm{N}$. The availability of $\mathrm{P}$ is secondarily important to Syringodium isoetifolium and possibly Halodule uninervis. Results of nutrient enrichment experiments support the hypothesis that the dramatic increase in seagrass distribution and biomass at Green Island over the past 50 yr has been caused by increases in nutrient availability. We suggest that nutrient limitation of seagrass growth is probably widespread on the GBR and may explain the absence of seagrass meadows from the cays of the southern GBR.

Acknowledgements. We would like to thank the many volunteers and staff who helped with this project; Nicola Udy, Tracey O'Connell, Christine Perry, Michael Rasheed, Frank Nissen and Karen Vidler for assistance with fieldwork, Louise Johns for laboratory assistance and Sharlene Blakeney for her assistance with the production of the GIS base map. The research was supported through postgraduate funding from the Botany Department, University of Queensland, a grant to W.C.D. from the ARC. The CRC for the Ecological Sustainable Development of the GBR through the Queensland Department of Primary Industry (QDPI) provided field support and mapping. Scotts Australia kindly provided the Osmocoate for this research. Aerial photographs were reproduced with permission of the Department of Natural Resources, Queensland.

\section{LITERATURE CITED}

Abal E, Dennison WC (1996) Seagrass depth range and water quality in southern Moreton Bay, Queensland, Australia. Mar Freshw Res 47(6):763-771

Agawin NSR, Duarte CM, Fortes MD (1996) Nutrient limitation of Philippine seagrasses (Cape Bolina, NW Philippines): in situ experimental evidence. Mar Ecol Prog Ser $138: 233-243$

Allan R, Johns RB (1989) Anthropogenic inputs into Green Island sediments. Unpublished report to GBRMPA (Great Barrier Reef Marine Park Authority), Townsville

Alongi DM, Boto KG, Robertson AI (1992) Nitrogen and phosphorous cycles. In: Robertson AI, Alongi DM (eds) Tropical mangrove ecosystems, Coastal and estuarine studies edn, Vol 41. American Geophysical Union, Washington, DC

Australian Littoral Society (1990) Great Barrier Reef resource inventory. Cairns section reefs and islands. (Accessed through GBRMPA; Great Barrier Reef Marine Park Authority) 
Bach S, Josselyn M (1978) Mass blooms of the alga Cladophora in Bermuda. Mar Pollut Bull 9:34-37

Baldwin CL (1992) Impact of elevated nutrients in the Great Barrier Reef. Research Publication No. 20, GBRMPA, Townsville

Baxter IN (1990) Green Island information review. Research publication No. 25, GBRMPA, Townsville

Bell PRF (1992) Eutrophication and coral reefs - some examples in the Great Barrier Reef lagoon. Wat Res 26:553-568

Bulthius DA, Woelkerling WJ (1981) Effects of in situ nitrogen and phosphorus enrichment of the sediments on the seagrass Heterozostera tasmanica (Martens ex Aschers.) den Hartog in Western Port, Victoria, Australia. J Exp Mar Biol Ecol 53:193-207

Bulthuis DA, Axelrad DM, Mickelson MJ (1992) Growth of the seagrass Heterozostera tasmanica limited by nitrogen in Port Philip Bay, Australia. Mar Ecol Prog Ser 89:269-275

Cambridge ML, McComb AJ (1984) The loss of seagrass in Cockburn Sound, Western Australia. I. The time course and magnitude of seagrass decline in relation to industrial development. Aquat Bot 20:229-243

Capone DG (1983) Nitrogen fixation. In: Carpenter EJ, Capone DG (eds) Nitrogen in the marine environment. Academic Press, New York, p 334-342

Capone DG, Dunham SE, Horrigan SG, Duguay LE (1992) Microbial nitrogen transformations in unconsolidated coral reef sediments. Mar Ecol Prog Ser 80:75-88

Dennison WC (1990a) Leaf production. In: Philips RC, McRoy $C P$ (eds) Seagrass research methods. UNESCO, Paris, p $77-79$

Dennison WC (1990b) Rhizome/root production. In: Philips RC, McRoy CP (eds) Seagrass research methods. UNESCO, Paris, p 81-82

Duarte CM (1990) Seagrass nutrient content. Mar Ecol Prog Ser 67:201-207

Duarte CM (1995) Submerged aquatic vegetation in relation to different nutrient regimes. Aquat Bot 41:87-112

Duarte CM, Merino M. Gallegos M (1995) Evidence of iron deficiency in seagrass growing above carbonate sediments. Limnol Oceanogr 40:95

Entsch B, Monks SA, Griffith JK, Llewellyn LE (1983) Indications from photosynthetic components that iron is a limiting nutrient in primary producers on coral reefs. Mar Biol 73:17-30

Erftemeijer PLA, Stapel J, Smekens MJE, Drossaert WME (1994) The limited effect of in situ phosphorous and nitrogen additions to seagrass beds on carbonate and terrigenous sediment in South Sulawesi, Indonesia. J Exp Mar Biol Ecol 182:123-140

Fisher TR, Butt AJ (1994) The role of nitrogen and phosphorus in Chesapeake Bay anoxia. In: Nelson S, Elliot P (eds) Perspectives on Chesapeake Bay, advances in estuarine sciences. Chesapeake Research Consortium, Inc, Washington, $\mathrm{p} 18$

Fourquirean JW, Zieman JC, Powell GVN (1992a) Phosphorus limitation of primary production in Florida Bay: evidence from C:N:P ratios of the dominant seagrass Thalassia testudinium. Limnol Oceanogr 37:162-171

Fourqurean JW, Zieman JC, Powell GVN (1992b) Relationships between porewater nutrients and seagrasses in a subtropical carbonate environment. Mar Biol 114:57-65

Furnas MJ, Mitchell AW, Wellington J, Brady B (1988) Dissolved and particulate nutrients in waters of the Whitsunday Island Group. Research Publication No. 16, Great Barrier Reef Marine Park Authority, Townsville, p 86

Furnas M, Mitchell AW, Skuza M (1995) Nitrogen and phosphorus budgets for the central Great Barrier Reef shelf.
Research Publication No. 36, Great Barrier Reef Marine Park Authority, Townsville, p 194

Gagan MK, Chivas AR, Herczeg AL (1990) Shelf-wide erosion, deposition, and suspended transport during Cyclone Winifred, Central Great Barrier Reef, Australia. J Sedim Petrol 60(3):456-470

Grice AM, Loneragan NR, Dennison WC (1996) Light intensity and the interactions between physiology, morphology and stable isotope ratios in five species of seagrass. $J$ Exp Mar Biol Ecol 195:91-110

Harris GP (1996) Catchments and aquatic ecosystems: nutrient ratios, flow regulation and ecosystem impacts in rivers like the Hawkesbury-Nepean. CSIRO and CRC for Freshwater Ecology, Canberra (N)

Hines ME, Knollmeyer SL, Tuugel JB (1989) Sulfate reduction and other sedimentary biogeochemistry in northern New England salt marsh. Limnol Oceanogr 34:578-590

Hixon MA (1997) Effects of reef fishes on corals and algae. Chapman and Hall, New York

Hopley D (1988) Anthropogenic influences on Australia's Great Barrier Reef. Aust Geogr 19(1):26-45

Howarth RW, Marino R (1988) Nitrogen fixation in freshwater, estuarine and marine ecosystems. Limnol Oceanogr 33: $688-701$

Jones AB (1999) Environmental management of aquaculture effluent: development of biological indicators and biological filters. PhD thesis, University of Queensland, Brisbane

Kenworthy WJ, Fonseca MS (1992) The use of fertilizer to enhance growth of transplanted seagrasses Zostera marina L. and Halodule wrightii Aschers. J Exp Mar Biol Ecol 163:141-161.

Kinsey DW (1991) Can we resolve the nutrient issue for the reef? Search 22:119-121

Klumpp DW, Done T, McKinnon AD, Brunskill GJ, Robertson A. (1997) Response of nearshore reefs to nutrient enhancement: Phase 1 of project: Baseline information on nutrient concentrations, primary production and reef community structure. Unpublished report to the Great Barrier Reef Marine Park Authority, Townsville

Kuchler D (1978) Coral cay shoreline movements: historical and seasonal patterns: Green Island, Great Barrier Reef, Australia. Honours Thesis, James Cook University, Townsville

Kuchler DA (1982) Green Island coral cay, Great Barrier Reef, Australia: a collection of historical photographs (1925-1978). Presented to the Great Barrier Reef Marine Park Authority, Townsville

Kuhlmann D (1988) The sensitivity of coral reefs to environmental pollution. Ambio 17(1):13-21

Kuo J, McComb AJ (1989) Seagrass taxonomy, structure and function. In: Larkum AWD, McComb AJ, Shepherd SA (eds) Biology of seagrasses. Elsevier, New York, p 6-73

Lapointe B (1989) Caribbean coral reefs: are they becoming algal reefs? Sea Frontiers Mar-Apr:82-91

Larcombe P, Woolfe K (eds) (1995) Great Barrier Reef: terrigenous sediment flux and human impacts. CRC Reef Research Centre, Research Symposium Proceeding Townsville

Lee Long WJ, Mellors JE, Coles RG (1993) Seagrasses between Cape York and Hervey Bay, Queensiand, Australia. Aust J Mar Freshw Res 44:19-31

Lee Long WJ, Coles RG, McKenzie LJ (1997) Impacts on and responses of seagrasses in the Great Barrier Reef - issues for management. In: Yellowlees D, Crossland J (eds) Great Barrier Reef Science, Use and Management Conference. James Cook University of North Queensland, Townsville, p 101-106 
Lide DR (1994) Handbook of chemistry and physics. CRC Press, London

Maragos J, Evans C, Holthus P (1985) Reef corals in Kaneohe Bay six years before and after termination of sewage discharges. Proc 5th Int Coral Reef Congress, Tahiti 4: 188-197

McClanahan TR (1997) Primary succession of coral-reef algae: differing patterns on fished versus unfished reefs. J Exp Mar Biol Ecol 218(1):77-102

McGlathery KJ (1995) Nutrient and grazing influences on a subtropical seagrass community. Mar Ecol Prog Ser 122 $239-252$

Mellors JE (1991) An evaluation of a rapid visual technique for estimating seagrass biomass. Aquat Bot 42:67-73

Mitchell AW, Reghenzani JR, Hunter H, Bramley RGV (1996) Water quality and nutrient fluxes from river systems draining to the Great Barrier Reef Marine Park. In: Hunter HM, Eyles AG, Rayment GE (eds) Downstream effects of land use. Department of Natural Resources, Brisbane, p 23--33

Moss AJ, Bennett J, Poplawski W, Shaw R, Moller G (1996) Land use factors affecting the condition of rivers, estuaries and bays in Southern Queensland. In: Hunter HM, Eyles $A G$, Raymond GE (eds) Downstream effects of land use. Department of Natural Resources, Brisbane, p 35-44

Orth RJ, Moore KA (1983) Submerged aquatic vegetation of the Chesapeake Bay: past, present and future. Science 22 $51-53$

Oweczkin J, Kerven G (1987) Methods of analysis for nitrogen, phosphorous, sulphur and potassium in plant material. Dept of Agriculture, University of Queensland

Parsons TR, Maita Y, Lalli CM (1989) A manual of chemical and biological methods for seawater analysis. Pergamon Press, Sydney

Penderson MF, Borum J (1992) Nitrogen dynamics of eelgrass Zostera marina during a late summer period of high growth and low nutrient availability. Mar Ecol Prog Ser 80:65-73

Penderson MF, Paling EI, Walker DI (1997) Nitrogen uptake and allocation in the seagrass Amphibolis antarctica. Aquat Bot 56:169-177

Perry CJ (1998) Microbial processes in seagrass sediments. $\mathrm{PhD}$ thesis, University of Queensland, Brisbane

Poiner IR, Conacher CA, Loneragan NR, Kenyon RA, Somers I (1993) Effect of cyclones on seagrass communities and penaeid prawn stocks of the Gulf of Carpentaria. CSIRO Marine Laboratories Report. CSIRO, Division of Fisheries, Marine Laboratories, Cleveland

Rose CW (1993) Soil erosion by water In: McTainsh G, Boughton WC (eds) Land degradation processes in Australia. Longman Cheshire, Melbourne, p 149-187

Short FT (1983) The seagrass: plant morphology and bed structure in relationship to sediment ammonium in Izembek Lagoon, Alaska. Aquat Bot 16:149-161

Short FT, Davie MW, Gibson RA, Zimmerman CF (1985) Evidence for phosphate limitation in carbonate sediments of the seagrass Syringodium filiforme. Estuar Coast Shelf Sci $20: 419-430$

Short FT, Dennison WC, Capone DG (1990) Phosphorus-limited growth of the tropical seagrass Syringodium filiforme in carbonate sediment. Mar Ecol Prog Ser 62:169-174

Short FT, Montgomery J, Zimmermann CF, Short CA (1993) Production and nutrient dynamics of a Syringodium filiforme Kutz. Seagrass Bed in Indian River Lagoon, Florida. Estuaries 16(2):323-334

Editorial responsibility: Otto Kinne (Editor),

Oldendorf/Luhe, Germany
Short FT, Burdick DM, Kaldy JE (1995) Mesocosm experiments quantify the effects of eutrophication on eelgrass, Zostera marina. Limnol Oceanogr 40:740-749

Silberstein K, Chiffings AW, McComb AJ (1986) The loss of seagrass in Cockburn Sound, Western Australia. III. The effect of epiphytes on productivity of Posidonia australis Hook. f. Aquat Bot 24:355-371

Smith GW, Hayasaka SS (1982) Nitrogenase activity associated with Halodule wrightii roots. Appl Environ Microbiol 43:1244-1248

Smith SV (1984) Phosphorus versus nitrogen limitation in the marine environment. Limnol Oceanogr 29(6):1149-1160

Steven A, Devlin M, Brodie J, Baer M, Lourey M (1996) Spatial influence and composition of river plumes in the central Great Barrier Reef. In: Hunter HM, Eyles AG, Rayment GE (eds) Downstream effects of land use. Department of Natural Resources, Brisbane, p 85-92

Stoddart DL, McLean RF, Hopely D (1978) Geomorphology of reef islands, northern Great Barrier Reef. Phil Trans R Soc Lond B 284:39-61

Taylor D, Nixon S, Granger S, Buckley B (1995) Nutrient limitation and the eutrophication of coastal lagoons. Mar Ecol Prog Ser 127:235

Tomaska DA, Lapointe BE (1991) Productivity and biomass of Thalassia testudinum as related to water column nutrient availability and epiphyte levels: field observations and experimental studies. Mar Ecol Prog Ser 75:9-17

Udy JW, Dennison WC (1996) Estimating nutrient availability in seagrass sediments. In: Kuo J, Phillips RC, Walker DI, Kirkman $H$ (eds) Seagrass biology: proceedings of an international workshop, Rottnest Island, Western Australia, 25-29 January 1996 edn. Sciences, UWA, Perth

Udy JW, Dennison WC (1997a) Growth and physiological responses of three seagrass species to elevated sediment nutrients in Moreton Bay, Australia. J Exp Mar Biol Ecol 217:253-277

Udy JW, Dennison WC (1997b) Seagrass physiological responses used to identify anthropogenic nutrient inputs. Mar Freshw Res 48:605-614

Udy JW, Dennison WC (1999) Seagrasses and sediment nutrients. In: Walker DI, Wells FE (eds) The seagrass, flora and fauna of Rottnest Island, Western Australia. Western Australian Museum, Perth, p 73-87

Walker D, Ormond R (1982) Coral death from sewage and phosphate pollution at Aqaba, Red Sea. Mar Pollut Bull 13(1):21-25

Welsh DT, Bourgues S, deWit R, Herbert RA (1996) Seasonal variations in nitrogen-fixation (acetylene reduction) and sulphate-reduction rates in the rhizosphere of Zostera noltii: nitrogen fixation by sulphate-reducing bacteria. Mar Biol 125:619-628

van Lent $F$, Verschuure JM (1994) Interspecific variability of Zostera marina L.(eelgrass) in the estuaries and lagoons of the southwestern Netherlands. If. Relation with environmental factors. Aquat Bot 48:59-75

van Lent F, Verschuure JM, van Veghel MLJ (1995) Comparative study on population of Zostera marina L. (eelgrass): in situ nitrogen enrichment and light manipulation. J Exp Mar Biol Ecol 185:55-76

van Woesik $R$ (1990) A preliminary examination on the hydrology and sedimentology of Green Island. Unpublished report to GBRMPA, Townsville

Submitted: January 12, 1998; Accepted: March 2, 1999 Proofs received from author(s): August 9, 1999 